Bangladesh J. Pl. Breed. Genet, 25(1): 17-23, 2012

\title{
GENETIC VARIABILITY AND CORRELATION IN EXOTIC CUCUMBER (Cucumis sativus L.) VARIETIES
}

\author{
M. Z. Ullah, M. J. Hasan ${ }^{1}$, A. Z. M. K. A. Chowdhury ${ }^{2}$, A. I. Saki ${ }^{3}$ \\ and A. H. M. A. Rahman ${ }^{4}$ \\ Energypac Agro Ltd. \\ Monipur, Hotapara, Gazipur \\ Bangladesh
}

\begin{abstract}
Twelve exotic cultivars of cucumber (Cucumis sativus) were grown to assess the presence of variability for desired traits and amount of variation for different parameters. Genetic parameters, correlations, partial correlation and regressions were estimated for all the traits. Analysis of variance revealed significant differences among entries for all the characters. The estimates of genotypic coefficient of variation (GCV) and phenotypic coefficient of variation (PCV) were high for yield per plant, fruits per plant, fruit weight and fruit length. Broad sense heritability estimates for various traits ranged from 42.26 to $89.55 \%$. Fruit yield per plant showed high significant positive correlation with fruits per plant, fruit weight, flesh thickness, fruit diameter and leaves per plant. Partial correlation was significant for fruits per plant and indicated these traits contributed over $70 \%$ to total fruit yield. By variability, correlation and regression analysis it was concluded that more fruits per plant and more fruit weight are major yield contributing factors in selecting high yielding cucumber cultivars.
\end{abstract}

Key words: PCV, GCV, correlation, regression, cucumber

\section{INTRODUCTION}

Cucumber (Cucumis sativus L.) belongs to the family cucurbitaceae. There are 30 Cucumis species found in Asia and Africa. Cucumber is a native to the tropics and is one of the oldest cultivated vegetable crops. It is known in the history for over 3,000 years (Yawalkar, 1985). Two distinct fruit morphotypes are found in Bangladesh, one is round fruited type called Khira grown in winter season and the other is long type called Shosha mostly in summer season (Ali et al., 1993). The basic idea in the study of variation is its partitioning into components attributable to different causes and the relative magnitude of these components determines the genetic properties of the population (Falconer and Mackay, 1996). This led to the concept of heritability, which specifies the proportion of the total variation that is due to genetic causes. Determining the components of variability in yield and its components will also enable us to know the extent of environmental influence on yield, taking into consideration of the fact that yield and its components are quantitative characters and are affected by environment (Ahmed

\footnotetext{
${ }^{1}$ Hybrid Rice, Plant Breeding Division, Bangladesh Rice Research Institute, ${ }^{2}$ GETCO Agro Vision, Bangladesh, ${ }^{3}$ Bangladesh Agricultural Development Corporation, Tangail, ${ }^{4}$ Bangabandhu Sheikh Mujibur Rahman Agricultural University, Gazipur 1706, Bangladesh.
} 
et al., 2007). Heritability provides an idea to the extent of genetic control for expression of a particular trait and the reliability of phenotype in predicting its breeding value (Chopra, 2000; Tazeen et al., 2009). High heritability indicates less environmental influence in the observed variation (Mohanty, 2003; Ansari et al., 2004; Songsri et al., 2008; Eid, 2009). It also gives an estimate of genetic advance a breeder can expect from selection applied to a population and help in deciding on a crop breeding method to chose (Hamdi et al., 2003; Gatti et al., 2005). Genetic advance which estimates the degree of gain in a trait obtained under a given selection pressure is another important parameter that guides the breeder in choosing a selection programme (Hamdi et al., 2003; Shukla et al., 2004). High heritability and high genetic advance for a given trait indicates that it is governed by additive gene action and, therefore, provides the most effective condition for selection (Tazeen et al., 2009).

This study was carried out to determine the extent of genetic variation among available cucumber genotypes with the specific objective of using suitable genetic parameters such as phenotypic and genotypic variances, phenotypic and genotypic coefficients of variation and genetic advance as a basis for future breeding work in cucumber.

\section{MATERIALS AND METHODS}

Twelve cucumber varieties obtained from germplasm bank of Energypac Agro Ltd., a research based private seed company situated in Monipur, Gazipur in Bangladesh and that were collected from two seed companies of Thailand (Table 1) were used for this study. The experiment was conducted at the Research \& Development farm of Energypac Agro Ltd, Monipur, Gazipur during Kharif-1, 2011 using Randomized Complete Block Design (RCBD) with 3 replicates. The unit bed size was $2 \mathrm{~m} \times 12 \mathrm{~m}$. There were 12 plants per bed with two rows. Plant spacing was $1 \mathrm{~m}$ by $1 \mathrm{~m}$. Two seeds were seeded in poly bag, after 16 days of seeding one healthy seedling was transplanted in main field.

Table 1. Name and source of cucumber varieties

\begin{tabular}{l|l|l|c|c|l}
\hline $\begin{array}{l}\text { Sl. } \\
\text { No. }\end{array}$ & $\begin{array}{l}\text { Variety } \\
\text { Name }\end{array}$ & Variety Source & $\begin{array}{l}\text { Sl. } \\
\text { No. }\end{array}$ & $\begin{array}{l}\text { Variety } \\
\text { Name }\end{array}$ & Variety Source \\
\hline 01 & Amata 5 & Chia Tai Seed Co., Thailand & 07 & Amata 7 & Chia Tai Seed Co., Thailand \\
02 & CUCT-505 & Chia Tai Seed Co., Thailand & 08 & CU-4412 & Lion Seed Co., Thailand \\
03 & CUCT-1401 & Chia Tai Seed Co., Thailand & 09 & CU-4421 & Lion Seed Co., Thailand \\
04 & CUCT-1220 & Chia Tai Seed Co., Thailand & 10 & CU-4305 & Lion Seed Co., Thailand \\
05 & Ninja 2 & Chia Tai Seed Co., Thailand & 11 & CU-4308 & Lion Seed Co., Thailand \\
06 & CUCT-607 & Chia Tai Seed Co., Thailand & 12 & CU-4317 & Lion Seed Co., Thailand \\
\hline
\end{tabular}

Recommended cultural practices were followed. Vegetative attributes measured were vine length and number of leaves at harvest. Reproductive attributes measured were days to flowering, days to harvest, fruit length, fruit diameter, flesh thickness, placental thickness, fruit weight, fruits per plant and yield per plan. The data obtained were subjected to Analysis of variance and significant means were separated using Duncan's Multiple Range Test (DMRT). The mean values were used for genetic analyses to determine Phenotypic Coefficient of Variation (PCV) and Genotypic Coefficient of Variation (GCV), according to Singh and Chaudhury (1985). The mean characters that showed significant variations were used to determine partial correlation and simple linear correlation coefficients according to Snedecor and Cochran (1967). A correlation matrix was drawn up using the linear correlation coefficients. 


\section{RESULTS AND DISCUSSION}

Statistical analysis of the means for the measured parameters showed significant differences among them except fruit diameter (Table 2). Estimates of genotypic coefficients, genetic advance as well as broad sense heritability are presented in Table 3 . The genotypic coefficient of variation (GCV) ranged from 0.34 for days to harvest to 3.27 for yield per plant while phenotypic coefficient of variation ranged from 0.41 to 3.96 for the same traits respectively. The highest phenotypic coefficients of variation (PCV) were observed for the characters yield per plant, fruit weight, fruits per plant and fruit length. It indicated that the apparent variation was not only due to genotype but also due to influence of environment. A comparatively low PCV was shown for days to harvest and days to flowering. It indicated that there was little influence of environment on the expression of character. Selection for improvement of such character had high scope for improvement (Okoye and Eneobong, 1992). In all the characters studied, a large environmental influence was observed in the manifestation of the traits studied as reflected by the differences in the values between phenotypic and genotypic differences (Ogbonna and Ubi, 2005). Heritable variation is useful for permanent genetic improvement (Singh, 2000). The most important function of the heritability in the genetic study of quantitative characters is its predictive role to indicate the reliability of the phenotypic value as a guide to breeding value (Dabholkar, 1992; Falconer and Mackay 1996). The high heritability estimates in characters like days to flowering (89.55\%) and fruit length (88.49\%) fruits per plant (80.03) indicated a high response to selection in these traits are presented in Table 3 . The estimate of genetic advance is more useful as a selection tool when considered jointly with heritability estimates (Johnson et al., 1955; Parnse, 1957). The attributes which had high to moderate heritability as well as genetic gain were fruit weight, fruit length, fruits per plant and days to flowering, indicating that these are simply inherited traits. Similar results were reported by Islam $e t$ al. (1993) for number of fruits per plant in cucumber.

Correlation matrix are presented in Table 4 suggested that fruit diameter, fruits per plant and flesh thickness correlated positively and significantly $(\mathrm{P}<0.001)$ with fruit yield. Again leaf per plant and fruit weight positively and significantly correlated $(\mathrm{P}<$ 0.01 ) with fruit yield while days to harvest showed negative correlation with yield indicating that early maturing varieties showed lower yields while the late maturing varieties had higher yields. Negative correlation of days to harvest with yield was earlier showed by Cramer and Wehner (2000). Vine length correlated positively and significantly with fruit length, fruit diameter, flesh thickness, fruit weight and leaves per plant. Similarly, there were positive and significant relationships between number of leaves and fruit diameter $(r=0.481)$, flesh thickness $(r=0.541)$ and fruit weight $(r=0.394)$. Fruit length were positively and significantly correlated with plant height $(\mathrm{r}=0.532)$, flesh thickness $(\mathrm{r}=0.658)$ and fruit weight $(\mathrm{r}=0.871)$. Fruit length was negatively and significantly correlated with fruits per plant $(\mathrm{r}=-0.561)$. Leaves per plant was significantly and positively association with plant height, fruit diameter and flesh thickness while positive association with fruits per plant. Cramer and Wehner (1998) reported that leaves per cucumber plant were positively correlated with total fruit number per plant in a cucumber population. In this study, there were strong and positive correlations between fruits per plant, fruit diameter, flesh thickness and leaves per plant with yield. Therefore a breeder interested in improvement in cucumber yield could either select plants with more leaves at the vegetative phase of growth, or select plants with more fruits and more fruit diameter, or be fairly certain of obtaining high yielding plants. 
Table 2. Means for vegetative and reproductive traits in cucumber varieties

\begin{tabular}{|c|c|c|c|c|c|c|c|c|c|c|c|}
\hline Variety & VL & DF & $\mathrm{DH}$ & LPP & FL & FD & FT & PT & FW & FPP & YPP \\
\hline 01 & $104.0 \mathrm{a}$ & $37.00 \mathrm{f}$ & $53.67 \mathrm{e}$ & $25.00 \mathrm{a}$ & $17.50 \mathrm{~b}$ & $4.83 \mathrm{ab}$ & $1.20 \mathrm{a}$ & $1.70 \mathrm{a}$ & $270.0 \mathrm{a}$ & $5.66 b$ & $1.51 \mathrm{~b}-\mathrm{d}$ \\
\hline 02 & $81.67 b$ & $42.00 \mathrm{~cd}$ & $58.00 \mathrm{a}-\mathrm{c}$ & $19.00 \mathrm{~b}-\mathrm{d}$ & $8.867 \mathrm{e}$ & $5.17 \mathrm{a}$ & $1.00 \mathrm{ab}$ & $1.56 \mathrm{ab}$ & $161.3 b c$ & $12.67 \mathrm{a}$ & $2.24 \mathrm{ab}$ \\
\hline 03 & $103.3 \mathrm{a}$ & $44.00 \mathrm{ab}$ & $57.67 \mathrm{~b}-\mathrm{d}$ & $23.33 \mathrm{ab}$ & $12.97 \mathrm{c}$ & $4.43 b c$ & $1.07 \mathrm{ab}$ & $0.93 d$ & $172.7 b$ & $10.67 \mathrm{a}$ & $1.83 \mathrm{a}-\mathrm{c}$ \\
\hline 04 & $92.33 \mathrm{ab}$ & $43.00 \mathrm{bc}$ & $58.00 \mathrm{a}-\mathrm{c}$ & $21.00 \mathrm{a}-\mathrm{c}$ & $13.50 \mathrm{c}$ & $4.83 \mathrm{ab}$ & $1.20 \mathrm{a}$ & $1.63 \mathrm{a}$ & $184.3 \mathrm{~b}$ & $12.33 \mathrm{a}$ & $2.53 \mathrm{a}$ \\
\hline 05 & $82.00 \mathrm{~b}$ & $41.00 \mathrm{~d}$ & $57.33 \mathrm{~cd}$ & $17.33 \mathrm{~cd}$ & $13.27 \mathrm{c}$ & $3.50 \mathrm{~d}$ & $0.96 \mathrm{ab}$ & $1.33 b c$ & $118.7 b-d$ & $5.66 \mathrm{~b}$ & $0.64 \mathrm{e}$ \\
\hline 06 & $91.67 \mathrm{ab}$ & $43.00 \mathrm{bc}$ & $59.67 \mathrm{a}-\mathrm{c}$ & $18.33 \mathrm{~b}-\mathrm{d}$ & $18.50 \mathrm{ab}$ & $4.33 b c$ & $1.07 \mathrm{ab}$ & $1.46 \mathrm{ab}$ & $250.0 \mathrm{a}$ & $4.33 b$ & $1.10 \mathrm{c}-\mathrm{e}$ \\
\hline 07 & $101.0 \mathrm{a}$ & $39.00 \mathrm{e}$ & $55.00 \mathrm{de}$ & $19.33 b-d$ & $20.33 a$ & $5.17 \mathrm{a}$ & $1.20 \mathrm{a}$ & $1.70 \mathrm{a}$ & $303.3 \mathrm{a}$ & $5.33 b$ & $1.63 b c$ \\
\hline 08 & $90.00 \mathrm{ab}$ & $42.00 \mathrm{~cd}$ & $59.33 a-c$ & $20.00 \mathrm{a}-\mathrm{d}$ & $12.67 \mathrm{c}$ & $4.60 \mathrm{~b}$ & $1.07 \mathrm{ab}$ & $1.46 \mathrm{ab}$ & $179.7 b$ & $9.66 \mathrm{a}$ & $2.01 \mathrm{ab}$ \\
\hline 09 & $80.33 b$ & $45.00 \mathrm{a}$ & $60.67 \mathrm{a}$ & $17.00 \mathrm{~cd}$ & 10.10de & $3.67 \mathrm{~d}$ & $0.83 b$ & $1.30 \mathrm{bc}$ & $82.33 \mathrm{~d}$ & $6.66 \mathrm{~b}$ & $0.60 \mathrm{e}$ \\
\hline 10 & $74.67 \mathrm{~b}$ & $44.00 \mathrm{ab}$ & $60.33 \mathrm{ab}$ & $15.00 \mathrm{~d}$ & $12.20 \mathrm{~cd}$ & $3.73 d$ & $0.83 b$ & $1.16 \mathrm{~cd}$ & $152.7 \mathrm{bc}$ & $5.00 \mathrm{~b}$ & $0.81 \mathrm{de}$ \\
\hline 11 & $80.33 b$ & $38.00 \mathrm{ef}$ & $53.67 \mathrm{e}$ & $16.33 \mathrm{~cd}$ & $11.17 \mathrm{c}-\mathrm{e}$ & $4.03 \mathrm{~cd}$ & $0.93 b$ & $1.43 \mathrm{a}-\mathrm{c}$ & $121.3 b-d$ & $12.33 \mathrm{a}$ & $1.50 \mathrm{~b}-\mathrm{d}$ \\
\hline 12 & $78.00 \mathrm{~b}$ & $37.00 \mathrm{f}$ & $55.00 \mathrm{de}$ & $19.00 \mathrm{~b}-\mathrm{d}$ & $9.267 \mathrm{e}$ & $4.03 \mathrm{~cd}$ & $0.83 b$ & $1.53 \mathrm{ab}$ & $98.33 \mathrm{~cd}$ & $11.67 \mathrm{a}$ & $1.22 \mathrm{c}-\mathrm{e}$ \\
\hline MS & 318.23 & 24.06 & 18.63 & 24.44 & 39.97 & 1.03 & 0.06 & 0.15 & 14300.56 & 33.24 & 1.16 \\
\hline Significant & $* *$ & $* * *$ & $* * *$ & $* *$ & $* * *$ & $* *$ & $* *$ & $* * *$ & $* * *$ & $* * *$ & $* * *$ \\
\hline
\end{tabular}

Means followed by same letters in each column are not significantly different.

$* *=$ significant at $1 \%, * * *=$ significant at $0.1 \%$

Legend: $\mathrm{VL}=$ vine length $(\mathrm{cm}), \mathrm{DF}=$ days to flowering, $\mathrm{DH}=$ days to harvest, $\mathrm{LPP}=$ leaves per plant, $\mathrm{FL}=$ fruit length $(\mathrm{cm}), \mathrm{FD}=$ fruit diameter $(\mathrm{cm}), \mathrm{FT}=$ flesh thickness, PT = placental Thickness, FW = fruit weight $(\mathrm{g}), \mathrm{FPP}=$ fruits per plant, $\mathrm{YPP}=$ yield per plant $(\mathrm{kg})$ and $\mathrm{MS}=\mathrm{mean}$ sum of square. 
Selection to increase leaves and number of fruits would invariably result in increased fruit yield in cucumber (Afangideh et al., 2005). Islam et al. (1993) reported significant positive correlation between number of fruits per plant and yield and Ramirez et al. (1988) also observed significant positive correlations between number of fruits per plant and fruit yield in cucumber.

Table 3. Coefficient of variability genetic advance and heritability of various attributes of different cucumber varieties

\begin{tabular}{l|c|c|c|c|c|c|c}
\hline \multicolumn{1}{c}{ Attributes } & $\sigma^{2} \mathrm{~g}$ & $\sigma^{2} \mathrm{p}$ & $\mathrm{GCV}$ & $\mathrm{PCV}$ & $\mathrm{GA}$ & $\mathrm{GAM}$ & $\mathrm{h}^{2} \mathrm{~b}(\%)$ \\
\hline Vine length $(\mathrm{cm})$ & 76.23 & 89.54 & 0.82 & 1.22 & 12.20 & 13.82 & 45.99 \\
Days to flowering & 7.72 & 0.90 & 0.56 & 0.59 & 5.42 & 13.139 & 89.55 \\
Days to harvest & 5.42 & 2.36 & 0.34 & 0.41 & 4.00 & 6.9734 & 69.67 \\
Leaves per plant & 5.60 & 7.65 & 1.03 & 1.58 & 3.17 & 16.491 & 42.26 \\
Fruit length (cm) & 12.77 & 1.66 & 2.23 & 2.37 & 6.93 & 51.867 & 88.49 \\
Fruit diameter (cm) & 0.31 & 0.09 & 1.07 & 1.22 & 1.02 & 23.433 & 77.46 \\
Flesh thickness & 0.01 & 0.02 & 0.98 & 1.44 & 0.17 & 16.721 & 46.73 \\
Placental Thickness & 0.04 & 0.02 & 1.20 & 1.50 & 0.34 & 23.675 & 64.28 \\
Fruit weight (g) & 4377.06 & 1169.38 & 3.16 & 3.56 & 121.07 & 69.359 & 78.92 \\
Fruits per plant & 10.23 & 2.55 & 3.14 & 3.51 & 5.89 & 69.294 & 80.03 \\
Yield per plant $(\mathrm{kg})$ & 0.33 & 0.16 & 3.27 & 3.96 & 0.98 & 66.512 & 68.17 \\
\hline
\end{tabular}

$\sigma^{2} \mathrm{~g}=$ genotypic variance, $\sigma^{2} \mathrm{~g}=$ phenotypic variance, $\mathrm{GCV}=$ genotypic coefficient of variation, $\mathrm{PCV}=$ phenotypic coefficient of variation, $\mathrm{GA}=$ Genetic advance, $\mathrm{GAM}=$ genetic advance $(\%$ Mean), $h^{2} b=$ heritability in broad sense

Table 4. Correlation matrix between attributes studied and with fruit yield of cucumber varieties

\begin{tabular}{|c|c|c|c|c|c|c|c|c|c|c|}
\hline Attributes & $\overline{D F}$ & $\overline{\mathrm{DH}}$ & LP & FL & FD & FT & PT & FW & FP & YP \\
\hline VL & -0.008 & -0.282 & $0.686^{* * *}$ & $0.532 * *$ & $0.462 * *$ & $0.515 * *$ & -0.039 & $0.566 * *$ & -0.034 & $0.388^{*}$ \\
\hline DF & & $0.744 * *$ & -0.098 & -0.151 & -0.119 & -0.082 & $-0.528 * *$ & -0.128 & -0.084 & 0.020 \\
\hline DH & & & -0.220 & -0.145 & -0.204 & -0.242 & -0.255 & -0.160 & -0.220 & -0.208 \\
\hline LP & & & & 0.281 & $0.481 * *$ & $0.541 * *$ & 0.103 & $0.394 *$ & 0.126 & $0.467 * *$ \\
\hline FL & & & & & $0.404 *$ & $0.658 * *$ & 0.295 & $0.871 * *$ & $-0.561 * *$ & 0.102 \\
\hline FD & & & & & & $0.732 * *$ & $0.468 * *$ & $0.738 * *$ & 0.201 & $0.751 * *$ \\
\hline FT & & & & & & & $0.373 *$ & $0.782 * *$ & -0.014 & $0.613 * *$ \\
\hline PT & & & & & & & & $0.355^{*}$ & -0.008 & 0.227 \\
\hline FW & & & & & & & & & -0.326 & $0.424 * *$ \\
\hline FP & & & & & & & & & & $0.617 * *$ \\
\hline
\end{tabular}

$* \mathrm{P}>0.05, * * \mathrm{P}>0.01$

$\mathrm{VL}=$ Vine length $(\mathrm{cm})$; DF= Days to flowering; $\mathrm{DH}=$ Days to harvest; $\mathrm{LP}=$ Leaf per plant; FL= Fruit length $(\mathrm{cm})$; Fruit diameter $(\mathrm{cm}) ; \mathrm{FT}=$ Flesh thickness; PT= Placental Thickness; FW= Fruit weight; FP= Fruits per plant

Partial correlation was significant $(\mathrm{P}<0.001)$ for fruits per plant (Table 5) and indicated that fruits per plant contributed over $70 \%$ to total fruit yield. The significance of partial regression coefficients was also tested (Table 5). Linear regression analysis of yield on the basis of all yield components is given in Table 5. Yield showed a significant linear regression coefficient with fruits per plant and fruit weight. The selection of best regression equation done through backward elimination procedure revealed that fruits per plant and fruit weight were the most effective variables contributing to the yield. 
Table 5. Partial correlation and linear regression coefficients of vegetative and reproductive attributes on yield of cucumber varieties

\begin{tabular}{lccc}
\hline Attributes & $\begin{array}{c}\text { Partial } \\
\text { Correlation }\end{array}$ & $\begin{array}{c}\text { Linear Regression } \\
\text { Coefficients(b) }\end{array}$ & $\begin{array}{c}\text { t-test for } \\
\text { Significance (for b) }\end{array}$ \\
\hline Vine length (cm) & -0.103 & -0.069 & -0.51 \\
Days to flowering & $0.421^{*}$ & 0.332 & $2.31^{*}$ \\
Days to harvest & -0.223 & -0.145 & -1.14 \\
Leaf per plant & 0.214 & 0.121 & 1.09 \\
Fruit length (cm) & -0.079 & -0.098 & -0.39 \\
Fruit diameter (cm) & 0.082 & 0.083 & 0.41 \\
Flesh thickness & 0.128 & 0.097 & 0.64 \\
Placental Thickness & 0.185 & 0.104 & 0.94 \\
Fruit weight & 0.368 & 0.580 & $1.98^{*}$ \\
Fruits per plant & $0.781^{* * *}$ & 0.715 & $6.26^{* * *}$ \\
\hline
\end{tabular}

$*=$ significant at $5 \%, * * *=$ significant at $0.1 \%$.

From the above discussion, fruit weight, fruits per plant, fruit length and days to flowering were shown to have high to moderate genotypic variance, high heritability, greater genetic gain and significant positive correlation with yield. Selection can therefore be based on these characters and their phenotypic expression would be a good indicator of their genotypic potentiality. The remaining traits recorded lower scores in the four genetic parameters considered in this study and therefore offered less scope for selection as they were much more under the influence of the environment. Regression analysis also indicated fruits per plant and fruit weight as the most effective variables contributing to the grain yield. So, it is concluded that these two traits may be considered as the selection criteria for the improvement of cucumber fruit yield.

\section{REFERENCES}

Afangideh, U., E. A. Uyoh, M. Ittah and A. E. Uko. 2005. Morphological Characterization of Some Cultivars of Cucumber (Cucumis sativus L.) Journal of Sustainable Tropical Agricultural Research. 14: 13 -18.

Ahmed, N.C.B. and I. M. M. Khaliq. 2007. The inheritance of yield and yield components of five wheat hybrid populations under drought conditions. Indonesian Journal of Agricultural Science. 8(2): 53-59.

Ali, M., A. K. Mian and E. A. Mamun. 1993. Improvement of some cucurbits: In: Breeding high female bitterless cucumber. Proc. Workshop Res. Div. Veg. crops. 9-10 March, 1993. IPSA, Gazipur.

Ansari, B. A., K. A. Ansari and A. Khund. 2004. Extent of heterosis and heritability in some quantitative characters of bread wheat. Industrial Journal of Plant Science. 3: $189-192$.

Chopra, V. L 2000. Plant Breeding. Theory and Practice. 2nd ed. Oxford and IBH Pub. Co. Pvt. New Delhi.

Cramer, C.S. and T. C. Whener. 1998. Fruit Yield and Yield Component Means and Correlations of Four Slicing Cucumber Populations Improved through Six to Ten Cycles of Recurrent Selection. Journal of American Society of Horticultural Science. 123: 388-395.

Cramer, C. S. and T. C. Whener. 2000. Fruit Yield and Yield Component Correlations of Four Pickling Cucumber Populations. Cucurbit Genetics Cooperative Report. 23: 12-15. 
Dabholkar, A. R. 1992. Elements of biometrical genetics. Concept Publishing Company, New Delhi, India.

Eid, M. H. 2009. Estimation of heritability and genetic advance of yield traits in wheat (Triticum aestivum L.) under drought conditions. International Journal of Genetics and Molecular Biology. 1(7): 115- 120.

Falconer, D. S., and Mackay, T. F. C. 1996. Introduction to quantitative genetics. $4^{\text {th }}$ Edn., Benjamin Cummings, England, ISBN-10 : 0582243025.

Gatti, I., Anido, F.L., Vanina, C, Asprelli, P.and Country, E. 2005. Heritability and expected selection response for yield traits in blanched asparagus. Genetics and Molecular Research. 4(1): 67-73.

Hamdi, A., A. A. El-Chareib, S. A. Shafey and M. A. M Ibrahim. 2003. Genetic variability, heritability and expected genetic advance for earliness and seed yield from selections in lentil. Egypt Journal of Agricultural Research. 81(1): 125-137.

Islam, M. S., S. Khan, D. Khanam, A. Malek and A. M. M. Hoque. 1993. Genetic Variability and Path Analysis in Cucumber (Cucumis sativus L.). Bangladesh Journal of Plant Breeding and Genetics. 6: 45 -51.

Johnson, H. E., H. F. Robinson and R. E. Comstock. 1955. Estimates of Genetic and Environmental Variability in Soyabean. Agronomy Journal. 47: 314-318.

Mohanty, B. K. 2003. Genetic variability, heritability, correlation and path coefficient studies in tomato. Indian Journal of Agricultural Research. 37: 68-71.

Ogbonna, P. E. and I. U. Obi. 2005. Studies on Heritability of Yield and Yield Components in 'Egusi' Melon (Colocynthis citrullis L.). Proceedings of the Genetic Society of Nigeria 30th Annual Conference, Nsukka, pp.60-63.

Okoye, F. I. and Eneobong, E. E. 1992. Genetic Variability and Correlation Studies in the African Yam Bean (Sphenostylis stenocarpa). Nigerian Journal of Botany. 5: 75-83.

Parnse, M. C. 1957. Genetics of Quantitative Characters in Relation to Plant Breeding. Indian Journal of Genetics. 17: 318-328.

Ramirez, D. R., T. C. Wehner and C. H. Miller. 1988. Growth Analysis and Correlation Studies in Three Cucumber Lines Differing in Plant Habit. HortScience. 23(1): $145-148$.

Shukla, S., Bhargava, A., Chattergee, A. and Singh, S.P. 2004. Estimates of genetic parameters to determine variability for foliage yield and its different quantitative and qualitative traits in vegetable amaranth (A. tricolor). Journal of Genetics and Breeding. 58: 169-176.

Singh, B. D. 2000. Plant Breeding: Principles and Methods. Kalyani Publishers, New Delhi.

Singh, R. K. and B. D. Chaudhary. 1985. Biometrical Methods in Quantitative Analysis. Kaljuni Publishers. New Delhi.

Snedecor, G. W. and W. G. Cochran. 1967. Statistical Methods, 6th edn., Iowa State University Press. USA.

Songsri, P., Joglloy, S., Kesmala, T., Vorasoot, N., Akkasaeng, C.P.A. and Holbrook, C. 2008. Heritability of drought resistant traits and correlation of drought resistance and agronomic traits in peanut. Crop Science. 48: 2245-2253.

Tazeen, M., Nadia, K. and Farzana, N. N. 2009. Heritability, phenotypic correlation and path coefficient studies for some agronomic characters in synthetic elite lines of wheat. Journal of Food, Agriculture and Environment. 7(3-4): 278-282.

Yawalkar, K. S. 1985. Cucurbitaceous or vine crops. In: Vegetable crops of India Agric. Horticultural Publishing House, Nagpur, India. 